\title{
Ritka szisztémás gyógyszer-interakció: timololtartalmú szemcsepp és lerkanidipintabletta együttes alkalmazása során ismétlődően jelentkező syncope
}

\author{
Kun Edit dr. ${ }^{1}$ - Dienes Lóránt $d r^{2}{ }^{2}$ Simonyi Gábor $d .^{3}{ }^{3}$ Finta Ervin dr. ${ }^{4}$ \\ ${ }^{1}$ Dél-budai Egészségügyi Szolgálat Nonprofit Kft., Belgyógyászati Szakrendelés, Budapest \\ ${ }^{2}$ Szent Imre Egyetemi Oktatókórház, Szemészeti Profil, Budapest \\ ${ }^{3}$ Szent Imre Egyetemi Oktatókórház, Anyagcsere Központ, Budapest \\ ${ }^{4}$ Szent Imre Egyetemi Oktatókórház, VIP-I Profil, Budapest
}

\begin{abstract}
A hypertoniás betegek gondozása és terápiájának összeállítása különösen nagy odafigyelést igényel. A társbetegségek és egyidejúleg alkalmazott egyéb medikációk sorában figyelembe kell venni a glaucomát és a kezelésére használt szemcseppeket is. A szemcseppek hatóanyaga a ductus nasolacrimalison keresztül az orr és a garat nyálkahártyájáról, illetve a kötőhártya és a sclera erein keresztül az enterohepaticus 'first pass' effektus kikerülésével juthat a vérkeringésbe - úgy, mintha intravénásan adtuk volna. Ily módon szisztémás mellékhatásai és interakciói jelentkezhetnek. A szerzők bemutatnak egy beteget is, aki évek óta ismétlődő eszméletvesztés miatt állt különböző kivizsgálások alatt, negatív eredménnyel. A Hypertonia Ambulancián derült fény a timololt is tartalmazó kombinált szemcsepp és a tablettában adott kalciumantagonista közös oki szerepére. A szerzők felhívják a figyelmet arra, hogy a béta-receptor-blokkolókhoz köthető szisztémás mellékhatások (vérnyomásesés, bradycardia, légzészavar, depresszió) észlelése esetén mindig gondolni kell a szemcseppben bevitt béta-receptor-blokkoló oki szerepére. Számolni kell ugyanakkor a szisztémás gyógyszer-interakciók lehetôségével is. Különösen veszélyes lehet a dihidropiridin típusú kalciumantagonistával kialakult interakció. Ilyen esetben a szemész szakorvossal konzultálva célszerü a béta-blokkolót tartalmazó szemcseppet más hatástani csoportba tartozó szerre cserélni.
\end{abstract}

Orv Hetil. 2019; 160(8): 309-313.

Kulcsszavak: glaucoma, timololszemcsepp, lerkanidipin, interakció, hypotonia, syncope

\section{Infrequent systemic drug interaction: repeated syncope caused by combined} treatment with timolol-containing eye drops and lercanidipine tablet

\begin{abstract}
The control and planning of the treatment of hypertensive patients need specific attention. As regards concomitant diseases and treatments, glaucoma and the use of eye drops should be taken into consideration. The ingredients of the administered eye drops get through the nasolacrimal canal and can be absorbed by the nasal mucosa. Because of the lack of enterohepatic 'first pass' effect, they can act systemically - like after intravenous administration. This way they can cause systemic side effects. The authors present a case of a patient, too, who was examined and medically checked regularly for years with negative results because of repeated syncope. It became clear only at the Hypertension Centre that the timolol-containing combined eye drops caused the symptoms. The authors draw attention to the fact that in the case of systemic side effects which can be connected to beta-blocking agents (blood pressure fall, bradycardia, breathing disturbance, depression), the role of the eye drops should be taken into consideration. At the same time, the possibility of the systemic drug interactions should not be forgotten either. The interaction with dihydropyridine-type calcium-channel blockers can be of great importance. In these cases, after consultation with an ophthalmologist, the glaucoma treatment with eye drops containing beta-blockers should be modified.
\end{abstract}

Keywords: glaucoma, timolol eye drops, lercanidipine, interaction, hypotension, syncope 
Kun E, Dienes L, Simonyi G, Finta E. [Infrequent systemic drug interaction: repeated syncope caused by combined treatment with timolol-containing eye drops and lercanidipine tablet]. Orv Hetil. 2019; 160(8): 309-313.

(Beérkezett: 2018. szeptember 18.; elfogadva: 2018. október 18.)

\section{Rövidítések}

$\mathrm{ABMP}=$ (ambulatory blood pressure monitoring $) 24$ órás vérnyomásmérés; ACTH = (adrenocorticotrop hormone $)$ adrenokortikotrop hormon (a hipofízis elülső lebenyében termelődó mellékvesekéreg-stimuláló hormon); CT = (computed tomography) számítógépes tomográfia; OGYÉI = Országos Gyógyszerészeti és Élelmezés-egészségügyi Intézet

A glaucoma olyan betegségcsoport, melyre a retinalis ganglionsejtek progresszív pusztulása jellemző, és ez a folyamat együtt jár a betegségre jellemző jellegzetes és szintén progresszív látóidegfó- (papilla nervi optici) és látásfunkció- (például látótér-) eltérésekkel különböző patomechanizmusokon keresztül. A biológiai redundancia miatt (az optimális látáshoz szükségesnél 30-50\%-kal több ganglionsejtünk van) a glaucoma miatti sejtpusztuláshoz kapcsolódó eltérések sokáig tünetmentesek. A ganglionsejt-tartalék elvesztése után a látásfunkció romlása gyorsult ütemú. Mivel mai tudásunk szerint retinalis sejtek a születés után már nem képződnek, irreverzibilis látásromlás alakul ki [1]. A glaucoma prevalenciája világszinten $3,54 \%$ a teljes lakosság körében (primer nyílt és zárt zugú), a 40 év feletti kaukázusi populációban $2 \%$; előfordulása az életkor előrehaladtával növekszik (a 70 éven felüliek között 3-8-szor gyakoribb). Fejlett országokban a leggyakoribb típusa a primer nyitott zugú glaucoma (glaucoma simplex) [2]. Különböző általános vagy szemészeti betegségekhez társultan (gyulladások, sérülések, érújdonképző́dés, örökletes betegségek, gyógyszermellékhatás stb.) felléphet másodlagos glaucoma (secunder glaucoma). Jelenleg a glaucoma kezelésének egyetlen bizonyítottan hatékony módja a szemnyomás tartós csökkentése (lehetőleg < $18 \mathrm{Hgmm}$ ), így a diurnalis ingadozás minimalizálása (lehetôleg $<4$ Hgmm). A nyomáscsökkentésnek három útja van: szemcseppkezelés, lézeres beavatkozások és mútétek. Ezek kombináltan is alkalmazhatók $[1,3]$.

A szemnyomáscsökkentő szemcseppek 5 fó hatástani csoportba sorolhatók, a hatodikba pedig kombinációik tartoznak $[3,4]$.

1) Béta-receptor-blokkolók. A második leggyakrabban használt glaucomaellenes gyógyszercsoport; a csarnokvíz-termelődés gátlásával hatnak. Szisztémás mellékhatásaik közé tartozik a légzésfunkció-romlás, a bradycardia és a depresszió. Ezek csökkenthetôk az alkalmazás során a könnycsatorna ujjal történő elzárása révén (punctal occlusion) $[5,6]$.

2) Karboanhidrázbénítók. Szintén a csarnokvíz-termelődés gátlása révén hatnak. Szisztémás mellékhatásuk nem jelentős, gyakran keserú íz érzése a szájban (25\%ban). Szulfonamidallergia esetén nem adhatók [6].

3) Prosztaglandinanalógok. A csarnokvíz-elvezetést fokozzák. Viszonylag kevés a szisztémás mellékhatásuk, de magában a szemben okozhatnak változásokat (az iris színváltozása, szempilla-növekedés). Terhességben ellenjavalltak (potenciálisan teratogének) [6].

4) Parasympathomimeticum (pilokarpin). A trabecularis csarnokvíz elvezetésének növelése révén hat; tartós alkalmazás során mellékhatása lehet látásromlás, illetőleg az iris lenövése a szemlencse tokjához.

5) Sympathomimeticumok (alfa-2-receptor-agonisták). Hatásmechanizmusuk összetett: egyrészt csökkentik a csarnokvíz termelődését (ez a jelentősebb), másrészt fokozzák az elvezetődését. Mellékhatásuk lehet depresszió, alvászavar (gyerekeknél akár 76\%-ban), vérnyomásesés (5-9\%-ban), szájszárazság (5-9\%-ban) [7, $8]$.

6) Kombinált készítmények. A betegek együttmúködését javítják, mivel naponta kevesebb cseppentésre van szükség, mint a hatóanyagok külön-külön alkalmazásával. A kombinációban a hatóanyagok önállóan fejtik ki hatásukat, és a mellékhatások is a komponensek mellékhatásaiból adódnak. Az alábbi kombinációs csoportokat ismerjük:

prosztaglandinanalógok + béta-receptor-blokolók, karboanhidrázbénító + béta-receptor-blokkoló, alfa-receptor-agonista + béta-receptor-blokkoló, pilokarpin + béta-receptor-blokkoló, karboanhidrázbénító + alfa-receptor-agonista.

\section{A szemcseppek szisztémás hatásának alapja}

Az anatómiai viszonyok miatt a kötőhártyazsákba cseppentett hatóanyag több mint $80 \%$-a a ductus nasolacrimalison keresztül az orr és a garat nyálkahártyájára jut, ahonnan felszívódva a szisztémás keringésbe kerül. Az enterohepaticus elimináció ('first pass' effektus) kikerülésével pedig az így felszívódott hatóanyag úgy viselkedik, mintha intravénásan adtuk volna [9].

\section{Egy ájulós beteg}

A 60 éves nőbeteg távoli anamnézisében appendectomia és cholecystectomia, vastagbél-diverticulosis és kezelt hypercholesterinaemia szerepel. 10 éve fennálló mikroszkópos haematuriája miatt urológiai gondozás alatt áll; legutóbb 3 éve történt cisztoszkópia, negatív eredménnyel. Az akkor készült hasi CT diagnózisa: cysta he- 
patis, colon- és sigmabél-diverticulosis. A nefrológiai kivizsgálás eredménye l éve negatív volt, a vesebiopsziába nem egyezett bele. Hypertoniája 10 éve ismert és kezelt. 2015. augusztusban a bal szemét retinaleválás miatt operálták, majd jobb szemén szürkehályog-eltávolítás történt 2016-ban. A nagy myop beteg 2015. augusztus óta a bal szemén másodlagos zöld hályog miatt alkalmazta a lentebb említett szemcseppet (2016. július óta mindkét szemébe). Szemnyomás értékei a kezelés alatt 14-20 Hgmm között ingadoztak. I éve kezdődött ismétlődő collapsus miatti neurológiai és kardiológiai kivizsgálása gyakorlatilag negatív eredménnyel zárult. A coronariaCT eredménye: minimális atherosclerosis, érdemi szúkület nélkül. Endokrinológiai vizsgálati eredményei (plazmakortizol, ACTH, plazma renin/aldoszteron hányados) is a normális tartományon belüliek voltak.

Belgyógyászati rendelésünkre (Hypertonia és Nefrológia Ambulancia is) legutóbb 2 héttel korábban lezajlott, 1-2 percig tartó eszméletlenséggel járó ismétlődő collapsus miatt utalta háziorvosa.

Aktuális gyógyszerelése reggel $100 \mathrm{mg}$ acetilszalicilsav, reggel $5 \mathrm{mg}$ lerkanidipin $\left(\right.$ Lercaton $^{\circledR}$ ), este $80 \mathrm{mg}$ valzartán, este $10 \mathrm{mg}$ rozuvasztatin, reggel $1000 \mathrm{NE}$ $\mathrm{D}_{3}$-vitamin volt, és $2 \times 1$ csepp brimonidin + timolol tartalmú kombinált szemcseppet $\left(\right.$ Combigan $\left.^{\circledR}\right)$ alkalmazott, először csak a bal szembe, majd mindkét szembe.

Statusában érdemi eltérést nem észleltünk. Vérnyomása: 124/74 Hgmm, pulzus: 76/min. Laborparaméterei a vizeletüledékben látóterenként észlelt $4-10$ vörösvértesttől eltekintve a normális tartományon belül voltak.
24 órás vérnyomás-monitorozást végeztünk (ABPM05 készülékkel; Meditech Kft., Budapest), melynek eredményét mutatja az 1 ábra.

A vérnyomás-monitorozás során feltűnő volt a nappali hypotensio (nappali átlag: 121/69 Hgmm, éjjeli átlag: 127/65 Hgmm). Figyelemre méltó a reggeli vérnyomászuhanás. Rákérdezésre elmondta, hogy előtte alkalmazta a timololt is tartalmazó kombinált szemcseppet. Ugyanakkor megemlítendő a reggel szedett vérnyomáscsökkentő - 5 mg lerkanidipin - is. Ezt követően terápiamódosítási kéréssel visszairányítottuk kezelő szemész szakorvosához, aki prosztaglandinanalóg tafluproszt hatóanyagú szemcseppre váltott (2017. szeptember). A beteg collapsusai megszúntek. A kontroll-ABPM-vizsgálat (2. ábra) során már nem látszott sem a nappali hypotonia, sem a reggeli vérnyomászuhanás. A mellékhatás bejelentése az OGYÉI honlapján hivatalosan megtörtént.

\section{Megbeszélés}

A timolol intrinsic sympathomimeticus aktivitás nélküli, nem szelektív béta-receptor-blokkoló, amely szemcsepp formájában alkalmazva a csarnokvíztermelés mérséklése révén csökkenti a szemnyomást. A ductus nasolacrimalison keresztül az orr és a garat nyálkahártyájáról az enterohepaticus 'first pass' effektus kikerülésével juthat a vérkeringésbe - úgy, mintha intravénásan adtuk volna. Ily módon szisztémás mellékhatásai könnyen jelentkeznek. Ezek közé tartozik a légzésfunkció romlása, a bradycardia, a

\section{Vérnyomás $[\mathrm{mmHg}]$}

Pulzus [1/perc]

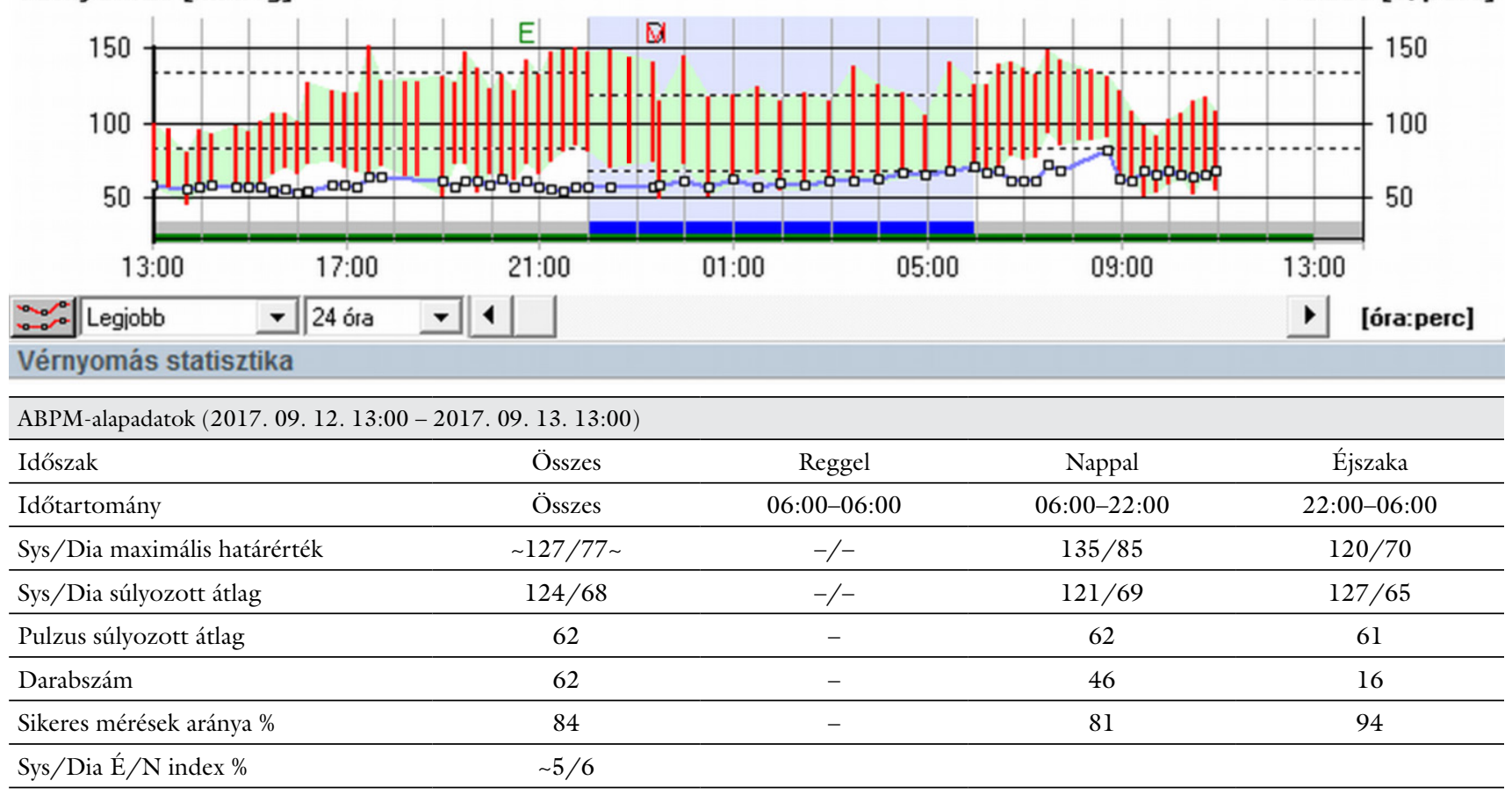

1. ábra 24 órás vérnyomás-monitorozás során igazolt vérnyomásesés. A reggeli timololadást követő vérnyomásesés reggel 9 órakor látható

$\mathrm{ABPM}=24$ órás vérnyomásmérés; Dia = diasztolés vérnyomás, amely a szívverések közötti szünetben mérhető; É = éjszaka; $\mathrm{N}=$ nappal; Sys = szisz tolés vérnyomás, a kar főartériájában mért nyomás, amely a szív összehúzódásakor alakul ki 


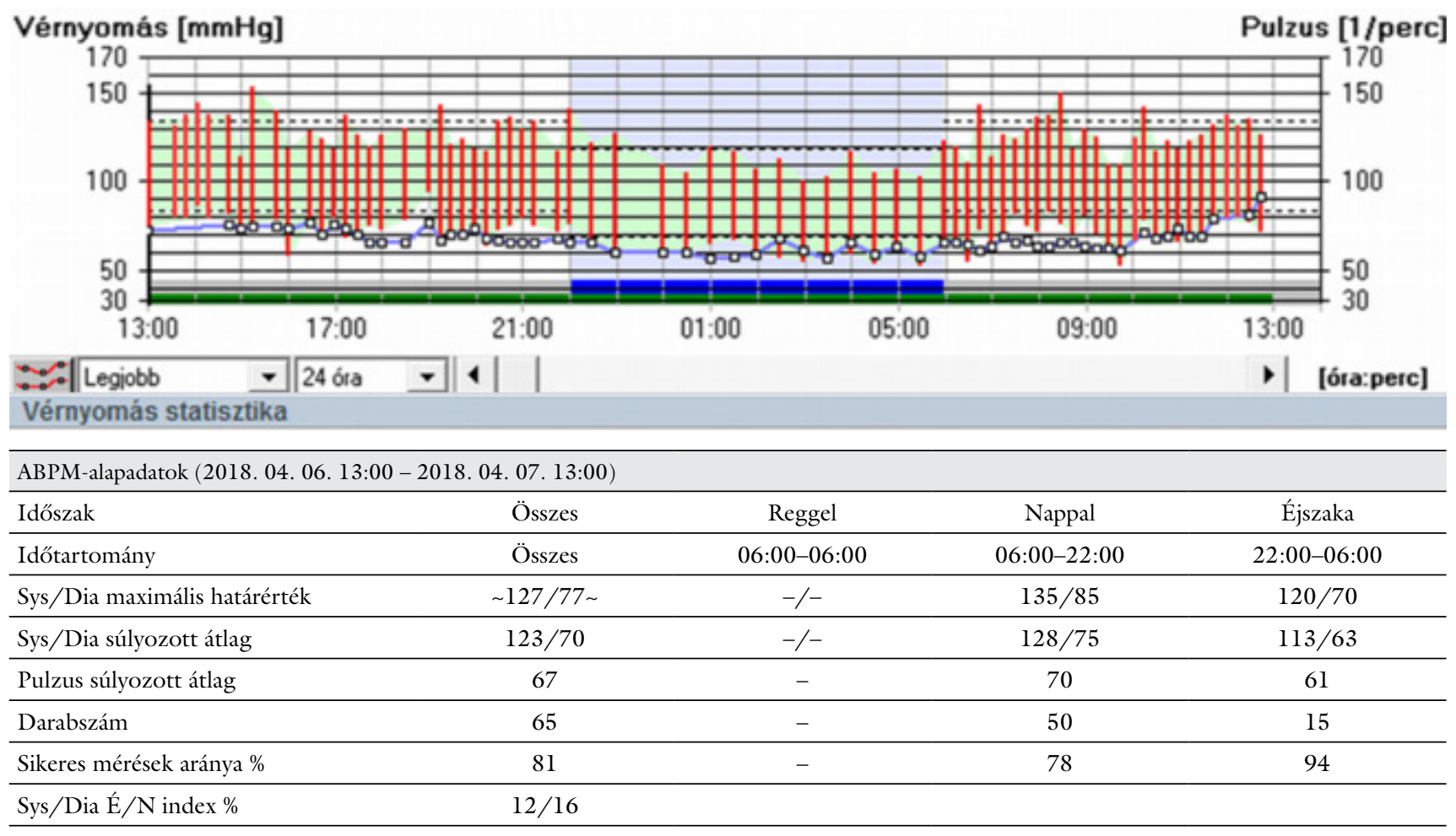

\begin{tabular}{l|l} 
2. ábra & 24 órás kontroll-vérnyomásmonitorozás. Már nem látszik a nappali hypotonia, és a reggel 9-kor látott vérnyomáscsökkenés is mérséklődött
\end{tabular} ABPM = 24 órás vérnyomásmérés; Dia = diasztolés vérnyomás, amely a szívverések közötti szünetben mérhető; É = éjszaka; $\mathrm{N}=$ nappal; Sys = szisztolés vérnyomás, a kar föartériájában mért nyomás, amely a szív összehúzódásakor alakul ki

depresszió, az impotencia és az elesések mellett a vérnyomáscsökkentő hatás is, amely a beteg által szedett antihipertenzívum effektusával összeadódva előre nem megjósolható vérnyomásesést okozhat [9]. A timololszemcsepphez köthető markáns vérnyomáscsökkenés hátterében egyéb okok is állhatnak. Ezek közé tartozik a timolol metabolizmusának megváltozása a lebontásáért felelős CYP2D6 izoenzim genetikai polimorfizmusa vagy az izoenzimet érintő gyógyszer-interakciók miatt [10]. A különböző gyógyszeradatbázisok egyaránt megemlítik a béta-blokkoló + dihidropiridin kalciumantagonista-kombináció által okozott hypotonia veszélyét, de a mindennapi gyakorlatban a belgyógyászok, vérnyomás-specialisták ritkán gondolnak arra, hogy a szemcseppnek nemcsak lokális, hanem szisztémás hatása is lehet. Nem hagyható szó nélkül a szemcsepp dozírozásának bizonytalansága sem. Számos beteg többször is cseppent, hogy biztosan bejusson a gyógyszer a szembe [11]. A 40 éve a piacon lévő, timololt tartalmazó szemcseppekhez köthető esések és syncope nem ismeretlenek a nemzetközi irodalomban [12], míg hazai példáról a szerzők nem találtak publikációt.

\section{Következtetés}

A hypertoniás betegek gondozása és terápiájának összeállítása különösen nagy odafigyelést igényel. A társbeteg- ségek és az egyidejûleg alkalmazott egyéb medikációk sorában figyelembe kell venni a glaucomát és a kezelésére használt szemcseppeket is. A béta-receptor-blokkolókhoz köthető szisztémás mellékhatások (vérnyomásesés, bradycardia, légzészavar, depresszió) észlelése esetén mindig gondolni kell a szemcseppben bevitt bétareceptor-blokkoló oki szerepére, illetve az egyidejúleg szedett vérnyomáscsökkentőkkel, főleg kalciumantagonistákkal fellépő interakciókra. Ilyen esetben a szemész szakorvossal konzultálva célszerü a béta-blokkolót tartalmazó szemcseppet más hatástani csoportba tartozó szerre cserélni.

Anyagi támogatás: A közlemény megírása anyagi támogatásban nem részesült.

Szerzői munkamegosztás: K. E., D. L.: A kézirat alapjául szolgáló eset menedzselése, irodalomkutatás, a kézirat megszövegezése. S. G.: Irodalomkutatás, konzultációk, a kézirat megszövegezése. F. E.: Irodalomkutatás, konzultációk, a közös munka összehangolása, a kézirat megszövegezése. A cikk végleges változatát valamennyi szerző elolvasta és jóváhagyta.

Érdekeltségek: A szerzőknek nincsenek érdekeltségeik. 


\section{Köszönetnyilvánítás}

Köszönet illeti $D r$. Szabó Anitát, a Szent Imre Egyetemi Oktatókórház intézetvezetô fógyógyszerészét az interakciók részletes kutatásáért és a gyógyszermellékhatás-bejelentésben nyújtott segítségért.

\section{Irodalom}

[1] Süveges I. Glaucoma. In: Süveges I. Ophthalmology. [Zöldhályog. In: Süveges I. Szemészet.] Medicina Könyvkiadó, Budapest, 2010; pp. 266-287. [Hungarian]

[2] Tham YC, Li X, Wong TY, Quigley HA, et al. Global prevalence of glaucoma and projections of glaucoma burden through 2040: a systematic review and meta-analysis. Ophthalmology 2014; 121: 2081-2090.

[3] Khaw PT, Shah P, Elkington AR. ABC of eyes. Glaucoma - 2: treatment. BMJ 2004; 328: 156-158.

[4] European Glaucoma Society Terminology and Guidelines for Glaucoma. 4th Edition - Chapter 3: Treatment principles and options. Supported by the EGS Foundation. Br J Ophthalmol. 2017; 101: 130-195.

[5] Glaucoma Research Foundation. Video: putting in eye drops. San Francisco, CA, 2018. Available from: https://www.glaucoma.org/treatment/putting-in-eye-drops.php [accessed: March $10,2018]$.
[6] Inoue K. Managing adverse effects of glaucoma medications. Clin Ophthalmol. 2014; 8: 903-913.

[7] Al-Shahwan S, Al-Torbak AA, Turkmani S, et al. Side-effect profile of brimonidine tartrate in children. Ophthalmology 2005; 112: 2143

[8] Schuman JS. Effects of systemic beta-blocker therapy on the efficacy and safety of topical brimonidine and timolol. Brimonidine Study Groups 1 and 2. Ophthalmology 2000; 107: 1171-1177.

[9] Shell JW. Pharmacokinetics of topically applied ophthalmic drugs. Surv Ophthalmol. 1982; 26: 207-218.

[10] Volotinen M, Hakkola J, Pelkonen O, et al. Metabolism of ophthalmic timolol: new aspects of an old drug. Basic Clin Pharmacol Toxicol. 2011; 108: 297-303.

[11] Holló G. Glaucoma: novelties that general practitioners should be aware of glaucoma. [Glaukóma: újdonságok, amit a háziorvosnak tudnia kell.] Magy Orv. 2012; 20(12): 14-16. [Hungarian]

[12] Müller ME, van der Velde N, Krulder JW, et al. Syncope and falls due to timolol eye drops. BMJ 2006; 332: 960-961.

(Finta Ervin dr., Budapest, Tétényi út 12-16., 1115 e-mail: ervin.finta@gmail.com) 